\title{
Sedimentation of organic and inorganic particulate material in Lindåspollene, a stratified, land-locked fjord in western Norway
}

\author{
Paul Wassmann
}

Institute of Marine Biology, University of Bergen, N-5065 Blomsterdalen, Norway

\begin{abstract}
Sedimentation of particulate material to the bottom (90 m) was measured in Lindåspollene, a land-locked, highly stratified, west Norwegian fjord, receiving fresh water from a small glacier free watershed. Five cylindrical sediment traps positioned at 10, 20, 40,70, and $85 \mathrm{~m}$ below the surface were exposed from April to November. Organic material comprised 40 to $60 \%$ of the sedimented matter. Sedimentation rates of particulate inorganic material (PIM) and particulate organic carbon (POC) decreased from 229 and 111 at $20 \mathrm{~m}$ to 71 and $22 \mathrm{~g} \mathrm{~m}^{-2} \mathrm{yr}^{-1}$, respectively, in the deeper water. Possible reasons for the low sedimentation in the stagnant water below $40 \mathrm{~m}$ are high mineralization rates in the upper $40 \mathrm{~m}$ and the lack of resuspension in the water below. Three pulses of POC and PON (particulate organic nitrogen) reached the bottom related to phytoplankton blooms in April and May. The pulse in April was the largest and the sedimented material consisted of unidentified aggregates, diatoms and some few fecal pellets. Few recognizable structures were found in the samples below $20 \mathrm{~m}$ except in April. This might indicate a low zooplankton grazing efficiency in April, but a high efficiency during the rest of the investigation period.
\end{abstract}

\section{INTRODUCTION}

Little is known about seasonal and depth-related changes in sedimentation of particulate material in Norwegian fjords. Wassmann (1981) and Gulliksen (1982) applied sediment traps to measure the supply of particulate material to the sediment surface in respectively Fanafjorden and Balsfjorden, whereas Skei (1983) measured the sedimentation in the poll Framvaren.

I present here the first data concerning the supply of particulate material to the sediment of Lindasspollene, a west Norwegian, highly stratified, land-locked fjord (Fig. 1). The supply of particulate matter to the sediment depends partly on changes in the structure and function of the pelagic system. Monitoring the sedimentation cycle is, therefore, one important step towards the understanding of marine ecosystems (Smetacek, 1980a). The investigation is part of a project at the Institute of Marine Biology, University of Bergen. The ultimate aim of this project is to develop a dynamic mathematical model of the flows of energy and matter in the ecosystem (Dahl et al., 1973).

The settling of particles through the water column and onto the sea bed has been subject of thorough investigations in different parts of the world for about 2 decades (Table 5). This flux represents a loss of particulate organic matter from the euphotic zone and the main source of food and energy for the benthos and planktonic organisms living below this zone. The sinking of particles is also of interest for chemical and geochemical processes in the water column as well as in the sediment.

Small, land-locked fjords ('polls') are very common along the west coast of Norway. Despite extensive investigations of 'polls' in the twenties and thirties (Gaarder, 1932; Gaarder and Bjerkan, 1934 ; Ålvik, 1934; Strøm, 1936) little research has been done in Norway on such ecosystems until the sixties (e.g. Dybern, 1967; Lännergren, 1975, 1976, 1978; Dale, 1978; Skjoldal and Lännergren, 1978).

Land-locked fjords have specific topographic, hydrodynamic and biological characteristics, such as shallow sills, limited water exchange and stagnant bottom waters, and food chains which differ from those of more open fjords (Matthews and Heimdal, 1980).

Land-locked fjords differ so much from typical fjords that it has been suggested that the Norwegian word 
'poll', which means land-locked fjord, should be recognızed and used internationally (Matthews and Heimdal, 1980). This term has previously been used in English articles by Klavestad (1957), Dybern (1967) and Lännergren $(1975,1976,1978)$ and will be used throughout this publication.

\section{MATERIALS AND METHODS}

Lindåspollene, situated about $40 \mathrm{~km}$ north of Bergen (Fig. 1), consists of 3 basins separated by shallow sills. the total volume of the poll. During winter, Lindasspollene is most often ice-covered. The tidal range is about $50 \mathrm{~cm}$ and the water exchange during one tidal cycle about $2 \%$ of the total volume (Dahl et al., 1973). The poll receives negligible amounts of domestic sewage.

Sedimentation of particulate material was measured at $10,20,40,70$, and $85 \mathrm{~m}$ depth at a central station with a water depth of $90 \mathrm{~m}$ (Fig. 1). Single traps were deployed during 12 periods, ranging from 6 to $31 \mathrm{~d}$ (average: $14 \mathrm{~d}$ ) with one exceptional period of $57 \mathrm{~d}$ (July to August), from April (end of ice cover) to

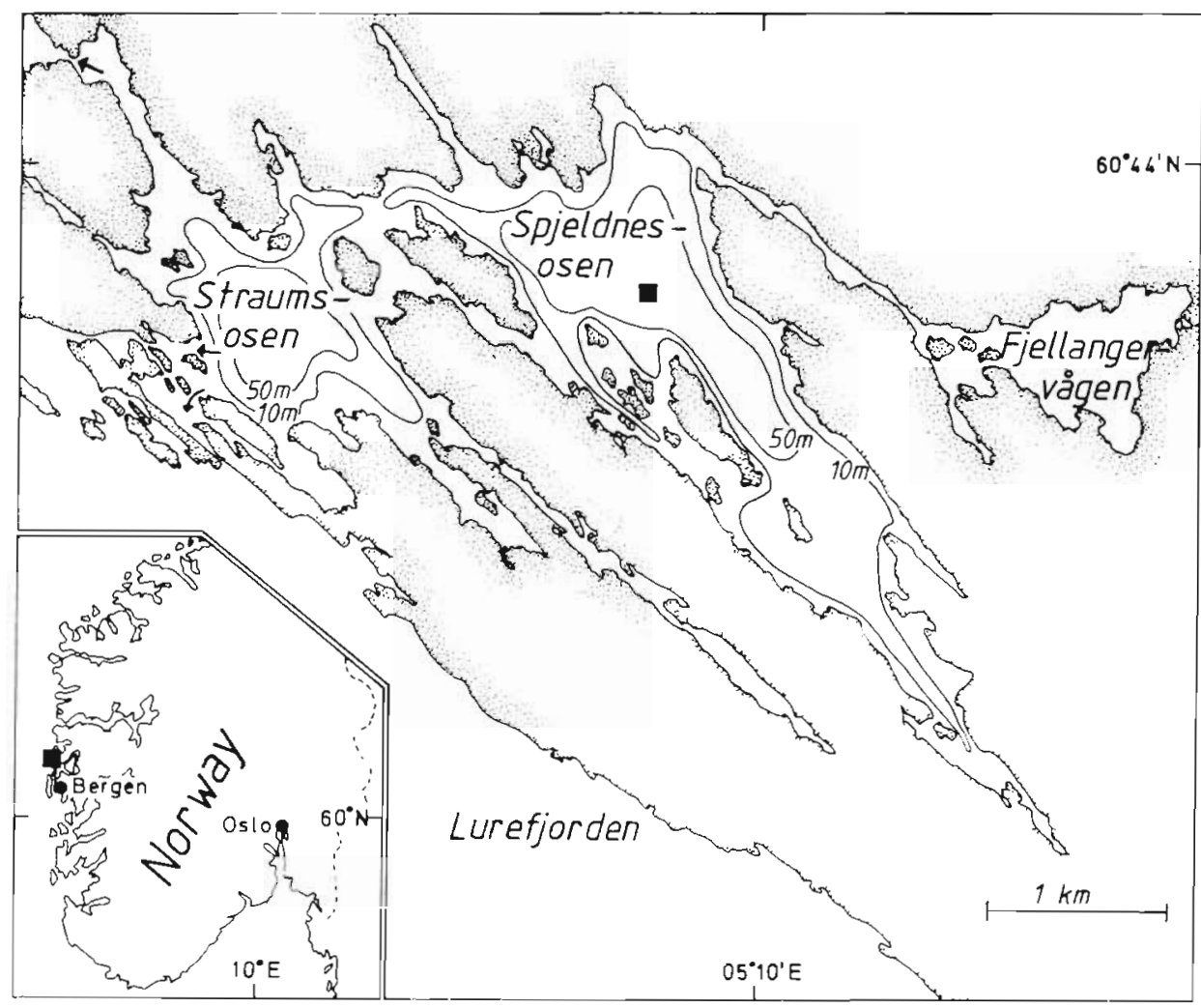

Fig. 1. Study area, Lind̊̊spollene. Arrows indicate outlets from Straumsosen to outer fjord. Sampling site

Lindåspollene is connected to the outer fjord (Lurefjorden) by 3 narrow sills less than $3 \mathrm{~m}$ deep. The restricted water exchange between the fjord outside and the basins leads to perıodically anoxic conditions in Straumsosen and Spjeldnesosen at long-term intervals. Exchange of bottom water was not observed during the present investigation. Below $20 \mathrm{~m}$ the water is rather homogenous in salinity and temperature (Aure, 1972), but the oxygen content at the sampling site (Fig 1) declined from 5.5 to $6.5 \mathrm{ml} \mathrm{O}_{2} \mathrm{l}^{-1}$ at $18 \mathrm{~m}$ to 0.6 to 1.4 $\mathrm{ml} \mathrm{O} \mathrm{I}^{-1}$ at $30 \mathrm{~m}$ (FIg. 2). $\mathrm{H}_{2} \mathrm{~S}$ was found in the bottom water below $70 \mathrm{~m}$.

Lindåspollene has a small, glacier-free watershed of about $35 \mathrm{~km}^{2}$ and receives about $7010^{6} \mathrm{~m}^{3}$ freshwater $\mathrm{yr}^{-1}$ (Lannergren, 1976) from a number of small streams. This discharge corresponds to about $50 \%$ of

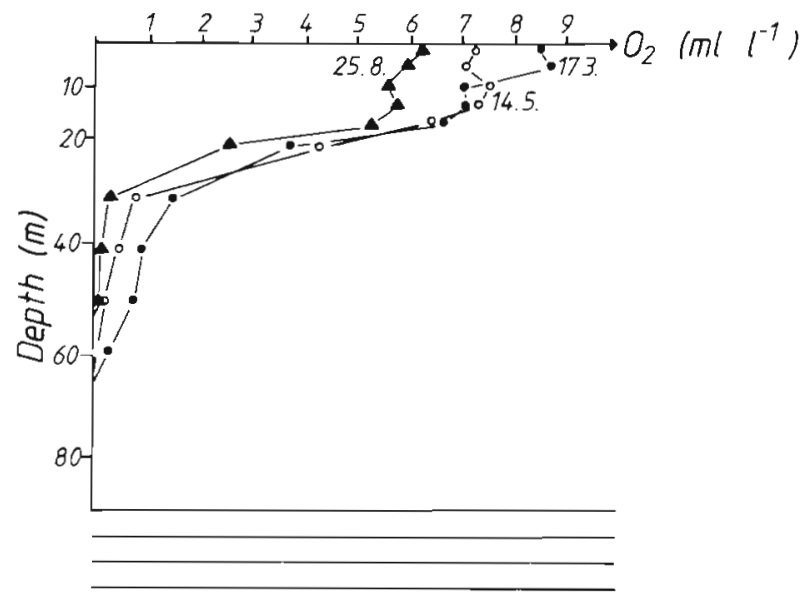

Fig. 2. Oxygen profiles in Lindåspollene between March and August 1981 
November 1981. Cylindrical sediment vessels made of stainless steel und with a hight of $500 \mathrm{~mm}$ and a diameter of $100 \mathrm{~mm}$ (i.e. a H/D-ratio of 5) were held in position by wire, clamps, anchor and subsurface floats (Wassmann, 1981).

In most short-term sedimentation measurements moored traps of various design have been used (Ansell, 1974; Webster et al., 1975; Hargrave et al., 1976; Knauer et al., 1979; Lorenzen et al., 1981). Despite continuing discussions on the use of traps for sedimentation measurements (Bloesch and Burns, 1980; Iseki et al., 1980; Blomquist and Håkanson, 1981), under moderate hydrodynamic conditions the use of cylindrical sediment vessels with a height/diameter greater than 3 seems to give reliable results (Hargrave and Burns, 1979; Blomqvist and Kofoed, 1981). To reduce degradation of trapped organic material inside the sediment vessels chloroform was added beforehand.

The collected material was suspended in 2.81 of seawater and kept homogenous by agitation. Subsamples (25 to $250 \mathrm{ml}$ ) for the analyses described below were taken from the agitated suspension and filtered onto pre-ashed Whatman GF/C (glass fiber) filters.

Total particulate material (TPM) was determined in triplicate on pre-weighed filters. The filtered material was rinsed twice with $20 \mathrm{ml}$ destilled water to remove salts and dried at $105^{\circ} \mathrm{C}$ for $24 \mathrm{~h}$. The fraction of particulate organic material (POM) and particulate inorganic material (PIM), respectively, was determined by weight loss on ignition at $450^{\circ} \mathrm{C}$ for $3 \mathrm{~h}$ (Dean, 1974).

Particulate organic carbon (POC) and nitrogen (PON) were determined with a CHN-analyser (Carlo Erba Strumentatione 1106). To remove any carbonates the filters were treated with $\mathrm{HCl}$ prior to analysis.

A $100 \mathrm{ml}$ subsample was preserved with buffered formaline (5\%) for microscopic examination; $20 \mathrm{ml}$ of this subsample were examined at $60 \times$ magnification. In the following text sedimentation rates are presented as per $\mathrm{m}^{2}$ and day/year. The average sedimentation rate for the period December to March was assumed equal to that for the investigated period April to November when calculating the annual rates.

\section{RESULTS}

All sedimentation rates measured with traps represent gross sedimentation rates, including both primary settling material and secondary settling material (resuspension, turbulent upward transport, and active transport by animals). If nothing else is mentioned sedimentation means gross sedimentation in this context.

\section{Sedimentation in relation to depth}

Fig. 3b shows the mean sedimentation rates of TPM, PIM, POC and PON as functions of depth. Sedimentation was greatest at $20 \mathrm{~m}$, decreasing markedly below, especially between 20 and $40 \mathrm{~m}$. Sedimentation rates at $20 \mathrm{~m}$ were from 3 (PIM) to 8 (PON) times greater than those at $85 \mathrm{~m}$ (Table 1).

The extent to which sedimentation differs vertically in the water column can be assessed by analyzing the coherence between sedimentation rates at various depths. Table 2 shows product moment correlation coefficients (Sokal and Rohlf, 1981) between seasonal sedimentation rates at the various depths. Only 5 out of 40 regressions were significantly curvilinear. It is therefore assumed that linear regression sufficiently describes the relation between the seasonal sedimentation rates at different depths. The sedimentation rates at $10 \mathrm{~m}$ were closely correlated with those at $20 \mathrm{~m}$. Also, the correlations between sedimentation rates at 40,70 , and $85 \mathrm{~m}$ were high, especially for POC and PON. On the other hand, the correlations between the sedimentation rates at 10 or $20 \mathrm{~m}$ and those at 40 , 70 , and $85 \mathrm{~m}$ were considerably lower. These results indicate different sedimentation regimes in the upper
Fig. 3. (a) Mean sedimentation rates of total particulate material (TPM), particulate inorganic material (PIM), particulate organic carbon (POC), and particulate organic nitrogen (PON; units $15^{-1}$ ) in relation to depths. (b) POC/PON-ratio (weight) of sedimented material, POC/TPM (\%) and PIM/ TPM $(\%)$ in relation to depth
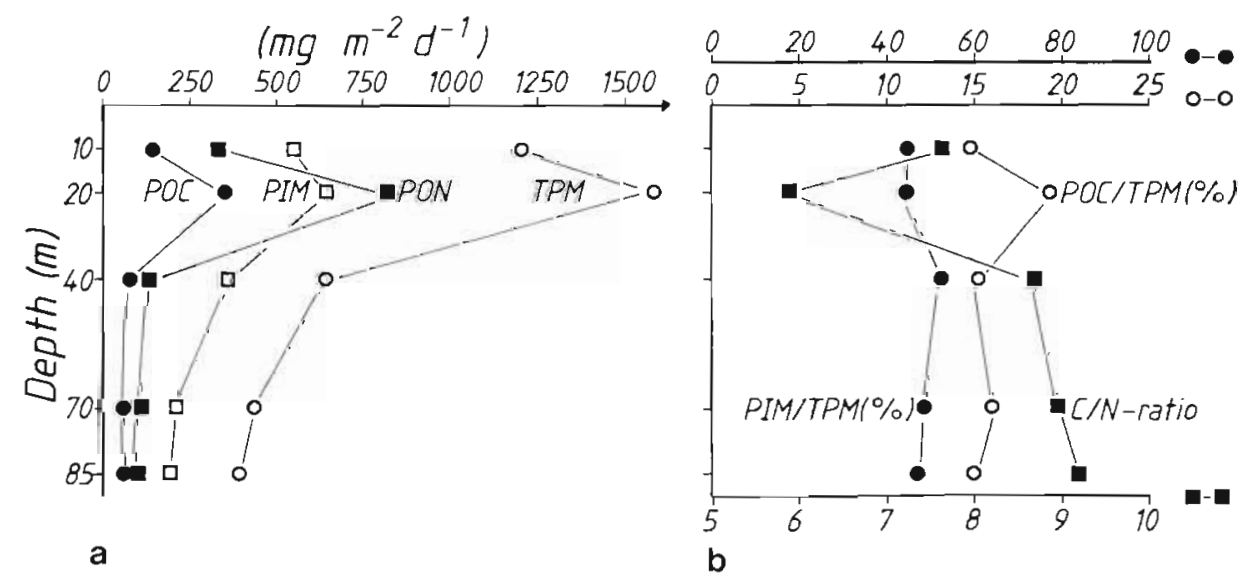
Table 1. Annual gross-sedimentation rates of total particulate material (TPM), particulate inorganic material (PIM), particulate organic carbon (POC), and particulate organic nitrogen (PON) at different depths in Lindåspollene in 1981, and decrease in sedimentation between $20 \mathrm{~m}$ and $85 \mathrm{~m}$ expressed as a percentage of that at $20 \mathrm{~m}$

\begin{tabular}{|c|c|c|c|c|c|c|}
\hline \multirow[t]{2}{*}{ Source } & \multicolumn{5}{|c|}{ Sedimentation $\left(\mathrm{g} \mathrm{m}^{-2} \mathrm{yr}^{-1}\right)$} & \multirow{2}{*}{$\begin{array}{c}\text { Percent decrease } \\
\text { in sedimentation } \\
\text { between } 20 \text { and } 85 \mathrm{~m}\end{array}$} \\
\hline & $10 \mathrm{~m}$ & $20 \mathrm{~m}$ & $40 \mathrm{~m}$ & $70 \mathrm{~m}$ & $85 \mathrm{~m}$ & \\
\hline TPM & 424.0 & 536.3 & 224.0 & 155.6 & 146.6 & 72.8 \\
\hline PIM & 191.3 & 228.6 & 128.1 & 75.1 & 70.9 & 69.0 \\
\hline POC & 52.9 & 110.5 & 29.3 & 25.8 & 22.9 & 79.3 \\
\hline PON & 8.2 & 19.9 & 3.4 & 2.8 & 2.5 & 87.5 \\
\hline
\end{tabular}

Table 2. Product moment correlation coefficients (r) comparing seasonal sedimentation rates of total particulate material (TPM), particulate inorganic material (PIM) $(n=12)$, particulate organic carbon (POC), and particulate organic nitrogen (PON) ( $\mathrm{n}=11)$ at different depths in Lindåspollene in 1981. ${ }^{*}=p<0.05 ; \cdots=p<0.01 ; \cdots=p<0.001$. Significant curvilinear regressions underlined

\begin{tabular}{|c|c|c|c|c|c|}
\hline Source & Depth $(\mathrm{m})$ & 20 & 40 & 70 & 85 \\
\hline TPM & $\begin{array}{l}10 \\
20 \\
40 \\
70\end{array}$ & $0.922 \cdots$ & $\begin{array}{l}0.302 \\
0.578^{\circ}\end{array}$ & $\begin{array}{l}0.626^{\cdots} \\
0.781^{\cdots} \\
0.742^{\cdots}\end{array}$ & $\begin{array}{l}0.567^{\circ} \\
0.760^{\circ} \\
0.769^{\circ} \\
0.984^{\circ}\end{array}$ \\
\hline PIM & $\begin{array}{l}10 \\
20 \\
40 \\
70\end{array}$ & $0.623^{\circ}$ & $\begin{array}{l}0.208 \\
0.718^{*}\end{array}$ & $\begin{array}{l}0.563^{\circ} \\
\frac{0.755^{\circ}}{0.654^{\circ}}\end{array}$ & $\begin{array}{l}0.517 \\
0.780^{\circ} \\
0.708^{*} \\
0.942^{\cdots}\end{array}$ \\
\hline $\mathrm{POC}$ & $\begin{array}{l}10 \\
20 \\
40 \\
70\end{array}$ & $0.956^{\cdots}$ & $\begin{array}{l}0.515 \\
0.572\end{array}$ & $\begin{array}{l}0.480 \\
0.556 \\
0.972 \cdots\end{array}$ & $\begin{array}{l}0.552^{\circ} \\
0.586^{*} \\
0.933^{*} \cdots \\
0.968^{*} \cdots \\
\end{array}$ \\
\hline PON & $\begin{array}{l}10 \\
20 \\
40 \\
70\end{array}$ & $0.977^{\cdots} \cdots$ & $\begin{array}{l}0.618^{\circ} \\
0.697^{\circ}\end{array}$ & $\begin{array}{l}0.619^{*} \\
0.712^{*} \\
0.962^{*}\end{array}$ & $\begin{array}{l}0.656^{\circ} \\
0.719^{\circ} \cdots \\
0.883^{\cdots} \cdots \\
0.961^{\circ} \cdots \\
\end{array}$ \\
\hline
\end{tabular}

and lower layers of Lindåspollene, with a looser coupling between the two layers than within each of them.

\section{Seasonal patterns of sedimentation}

The seasonal patterns of sedimentation of TPM, PIM, POC, and PON were not similar (Fig. 4). With regard to depth, the period of investigation can be separated into 2 main periods. In April and May the time variations in sedimentation, especially of POC and PON, were similar at all depths. For the rest of the period of investigation the sedimentation at 10 and $20 \mathrm{~m}$ differed markedly from that at greater depths. From July to November sedimentation rates for all components were fairly high at 10 and $20 \mathrm{~m}$, but low at 40,70 , and $85 \mathrm{~m}$. Time variations were almost uniform in the lower part of the water column during the last period.

Three maxima of phytoplankton biomass (as suspended chlorophyll a) in April and May in Lindåspol- lene (Skjoldal, unpubl.; no measurements available for the rest of 1981) coincided with 3 pulses of deposition of $P O C$ and $P O N$ at 20,40 , and $70 \mathrm{~m}$, indicating that particulate material derived from phytoplankton is transferred rapidly to the deeper part of the poll. Only 1 peak of sedimentation of POC and PON reached the depth of $85 \mathrm{~m}$ and coincided with the first and main phytoplankton bloom. Particulate organic material from the upper part of the water column was not rapidly transferred to the stagnant part of the water column from July to November, a period of maximum stratification. This implies a high decomposition rate in the water mass above the oxycline $(30 \mathrm{~m})$ or export of POM out of the area during this period.

\section{Nature of sedimented material}

Microscopic examination revealed that most of the material found in the traps, especially below $20 \mathrm{~m}$, 

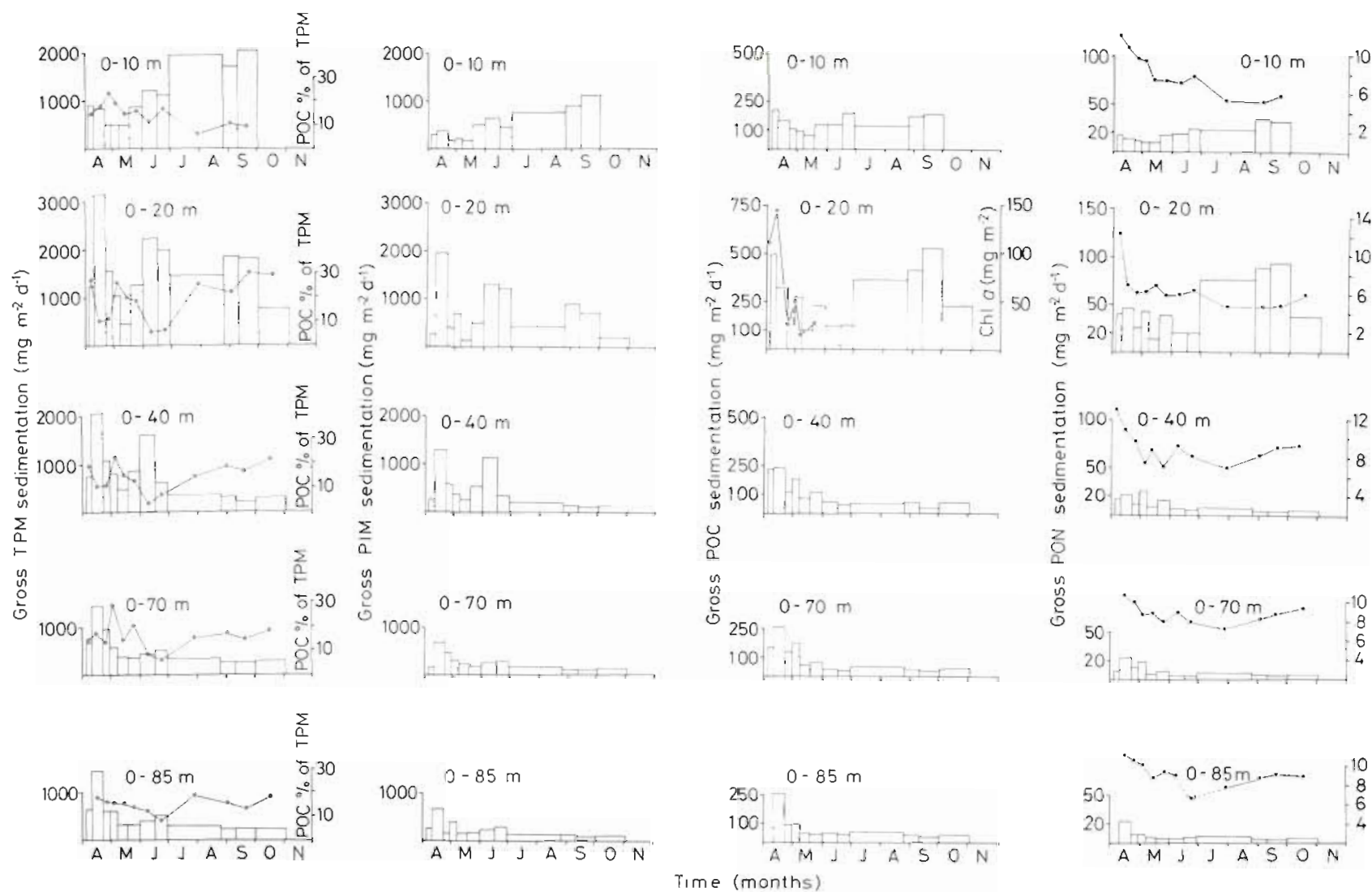

Fig. 4. Sedimentation rates of total particulate material (TPM), particulate inorganic material (PIM), particulate organic carbon (POC), and particulate organic nitrogen (PON) and the POC/PON-ratio (weight) and POC/TPM (\%) of the sedimented material at 10, 20, 40,70, and $85 \mathrm{~m}$ in the period April to November 1981 in Lindasspollene. Also shown is the chlorophyll a content in the upper $40 \mathrm{~m}$ of the water column

consisted of small aggregates and flakes without any recognizable structures. It is not clear, however, to what extent the preservation of the deposited material during exposure of the traps and during storage of the samples has influenced its appearance. Recognizable structures were mainly fecal pellets and diatoms, whereas dinoflagellates were rarely found.

Diatoms such as Skeletonema costatum, Thallassiosira sp., Chaetoceros sp. and Rhiizosolenia sp. were found at all depths during the peaks in sedimentation of POC and PON following the spring bloom. During the summer period, on the other hand, diatoms were rarely found in the traps below $20 \mathrm{~m}$.

Organic material (ash free dry weight) comprised in general more than $50 \%$ of the TPM deposited (Table 1). The relative content of POC varied between 4 and $30 \%$ with an average of $16 \%$ (Fig. 4).

Significant $(p<0.001)$ product moment correlations between precipitation (run-off from land) and the sedimentation rates of particulate material were found for the samples from $10 \mathrm{~m}$ depth, but not for the samples from $40 \mathrm{~m}$ and below (Table 3). Moreover, recognizable allochtonous material, such as leaves etc., was never found in the traps, indicating that particulate allochtonous material is of minor importance for the annual supply.

The relative POC content of the TPM showed greatest seasonal variations at $20 \mathrm{~m}$ and least variation at 10 and $85 \mathrm{~m}$ (Fig. 4). The patterns of variation were similar for the 20,40 , and $70 \mathrm{~m}$ samples, while being different for the samples from 10 and $85 \mathrm{~m}$. Since organic material represents a major part of the TPM

Table 3. Product moment correlation coefficients (r) comparing precipitation (river run-off) and sedimentation of total particulate material (TPM), particulate inorganic material (PIM), particulate organic carbon (POC), and particulate organic nitrogen (PON) at 10,20 , and $40 \mathrm{~m}$ in Lindasspollene in 1981. ${ }^{\cdot}=p<0.05 ; \cdots=p<0.01 ; \cdots=p<0.001$. Significant curvilinearity was not found

\begin{tabular}{|llllll|}
\hline $\begin{array}{c}\text { Depth } \\
(\mathrm{m})\end{array}$ & TPM & PIM & POC & PON & $\mathrm{n}$ \\
\hline 10 & $0.893^{\cdots} \cdots$ & $0.924^{\cdots} \cdots$ & $0.951^{\cdots} \cdots$ & $0.926^{\cdots} \cdots$ & 10 \\
20 & $0.605^{\circ}$ & 0.362 & $0.665^{*}$ & $0.627^{\circ}$ & 11 \\
40 & 0.244 & 0.216 & 0.397 & 0.441 & 11 \\
\hline
\end{tabular}


deposited and primary production is the main source of this organic material (Table 4), differences in the POC content of phytoplankton will influence the seasonal variations in the POC content of the TPM deposited. Diatoms and coccolithophorids, which contain much non-combustible material, showed blooms in April and June, respectively. Minima in the relative POC content at $20 \mathrm{~m}$ and below coincide with these blooms. The POC content of the sedimented matter was high and increasing from July to November at $20 \mathrm{~m}$ and below, despite the presumably high mineralization efficiency in the plankton during this period. Possibly, different sources for sedimentation of PIM and POC can also have caused seasonal variations in the POC content of the TPM.

The POC/PON-ratio of the sedimented material varied both with season and depth (Fig. 3 b and 4), revealing changes in the composition of the organic material. The mean POC/PON-ratios at the different depths show the reverse trend to that of sedimentation (Fig. 3b). The ratio decreased slightly from 10 to $20 \mathrm{~m}$, indicating less nitrogen depletion of deposited material at $20 \mathrm{~m}$. The POC/PON-ratio increased markedly between 20 and $40 \mathrm{~m}$, but only slightly between 40 and $85 \mathrm{~m}$. The pattern of seasonal variation in the POCPON-ratio were generally similar at all depths, with maximum values found in early April. Thereafter the ratios decreased to minima in July/August followed by a slight increase. The high POC/PON-ratios in April coincided with relatively high sedimentation rates at all depths. This indicates that the diatoms which comprised much of the sedimented material during this period were strongly nitrogen depleted.

\section{Flux of organic material to the sediment}

Annual sedimentation rates from Lindåspollene (based on daily mean sedimentation rates) were calculated to compare those rates with annual sedimentation rates given in the literature (Table 1); $29 \mathrm{~g} \mathrm{POC}$ $\mathrm{m}^{-2} \mathrm{yr}^{-1}$ are supplied to the stagnant water mass of the poll. A rough calculation of the supply and loss of POC in the upper $40 \mathrm{~m}$ at the central station (Table 4) shows that only $24 \%$ of the POC supply is transferred to the stagnant water. This implies that planktonic consumption and export are the most significant pathways for the POC flux in the upper part of the water column in Lindåspollene (Table 4).

Only $22 \mathrm{~g}$ POC $\mathrm{m}^{-2} \mathrm{yr}^{-1}$ are supplied to the sediment (Table 1). This supply is in part used by the benthos as energy source and most of the refractory matter is accumulated in the sediment. Anaerobic benthic metabolism, i.e. sulfate reduction, does exist in the sediment of Lindaspollene. Therefore, the accumu-
Table 4. Annual supply and loss of POC in the upper $40 \mathrm{~m}$ of Lindåspollene $\left(\mathrm{g} \mathrm{m}^{-2} \mathrm{yT}^{-1}\right)$

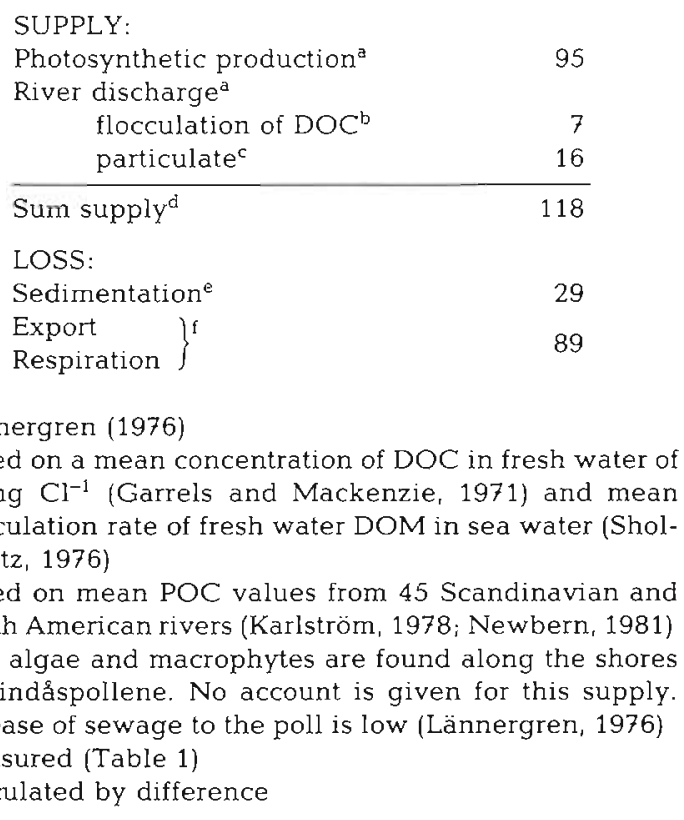

lation rate of $\mathrm{POC}$ has to be lower than $18 \%$ of the POC supply of the upper $40 \mathrm{~m}$ of the poll. Supposing a sediment water content of $94 \%$ (Pamatmat and Skjoldal, 1974; Skjoldal, unpubl.) and a specific weight of $2 \mathrm{~g} \mathrm{~cm}^{-3}$ dry sediment, the TPM sedimentation rate at $85 \mathrm{~m}$ (Table 1) is equivalent to sediment accumulation of less than $1.5 \mathrm{~mm} \mathrm{yr}^{-1}$.

The seasonal variation in sedimentation implies that the benthos at the sampling site receives more than $20 \%$ of its annual supply of POC during $5 \mathrm{wk}$ in April/ May. For the rest of the year the sediment receives

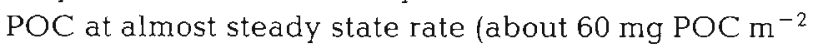
$\mathrm{d}^{-1}$ ).

\section{DISCUSSION}

The decrease of sedimentation with depth in Lindasspollene (Fig. $3 a$ and 4 ) is in contrast to the increase with depth found in other enviromments (Steele and Baird, 1972; Ansell, 1974; Hargrave and Taguchi, 1978; Platt, 1979; Smetacek, 1980a; Gulliksen, 1982). The increase in sedimentation rate with increasing depth is usually interpreted as a result of resuspension, but other explanations might also be in situ autotrophic production, fecal pellet production by migrating zooplankton (Hargrave and Taguchi, 1978), the morphology of fjords and bays (sediment focusing) (Hargrave and Kamp-Nielsen, 1977) and currents. 
The decreasing sedimentation with depth in Lindåspollene could be an artifact caused by different sampling efficiencies of the traps. The 5 sediment vessels are presumably subjected to different turbulence regimes at the various depths. In stagnant water a sediment vessel would catch the actual downward flow of particulate material regardless of the vessel design. The cylindrical traps used here have hydrodynamical qualities which, according to Hargrave and Bums (1979), Gardner (1980a, b), Blomqvist and Kofoed (1981) and Blomqvist and Håkanson (1981), give reliable results under the hydrodynamic conditions of this study. In a laboratory flume where the water current did not exceded $9.5 \mathrm{~cm} \mathrm{~s}^{-1}$, Gardner (1980a) showed that a cylindrical sediment vessel with an H/D-ratio of 2.3 collected particles at a rate equivalent to the downward flux. Bröckel (pers. comm.), however, found that increasing water flow resulted in increased sedimentation rates up to a specific water current velocity, which flushes the whole sediment vessel and thus results in a lower sedimentation rate. The mean turbulent energy per unit time supplied to the water below $40 \mathrm{~m}$ depth in Lindasspollene is only about $3 \%$ of the mean turbulent energy per unit time supplied to the top layer $(0$ to $10 \mathrm{~m}$ ) (Aure, 1972). The turbulent diffusion is, therefore, of minor importance below $40 \mathrm{~m}$ and the sediment vessels below $40 \mathrm{~m}$ are situated in almost stagnant water. Sediment vessels at 10 and $20 \mathrm{~m}$ are subjected to turbulence and the collecting efficiencies might be reduced. Compared to other coastal environments, where sedimentation vessels with an H/D-ratio of 5 were used (Hargrave and Burns, 1979; Blomqvist and Kofoed, 1981), the influence of water movement in Lindaspollene is thought to be of minor importance. The decrease in sedimentation with depth can, there- fore, not be explained by different catchment efficiencies.

The retrieval of the traps represents a critical step in this study because the traps were not closed during this operation. The effect of this was presumably small, however, since particles were never observed in the water above the deposited material on the bottom of the traps.

Due to the low oxygen content below $40 \mathrm{~m}$ (Fig. 2) most planktonic organisms have to stay above this depth. The consumption and the respiration of planktonic herbivores will lead to a decrease in particle concentration which can settle to the sediment. High zooplankton respiration rates directly above intense oxygen minimum zones are known from British Columbia fjords (Devol, 1981). The high concentration of animals in the upper $40 \mathrm{~m}$ of the water column in Lindåspollene produces a 'shadow effect' (Devol, 1981) reducing the sedimentation rate between 20 and $40 \mathrm{~m}$ (compare Fig. 2 and 3a).

In Lindåspollene resuspension is supposed to be of little importance at depths greater than $40 \mathrm{~m}$ since little turbulent energy is supplied to the water below (Aure, 1972). Therefore, the amount of collected matter at 20 and $40 \mathrm{~m}$ is supposed to reflect deposition of particulate material under conditions of turbulence and non-turbulence. From this point of view a diagram was made that illustrates differences in the deposition of POM in fjords and polls (Fig. 5). POM is produced in the euphotic zone of both water bodies. Due to this production net-sedimentation (primary settling material) increases down to the bottom of the euphotic zone if consumption is not excessive. Below this depth consumption by pelagic organisms leads to a decrease in net sedimentation in both areas. The turbulent water

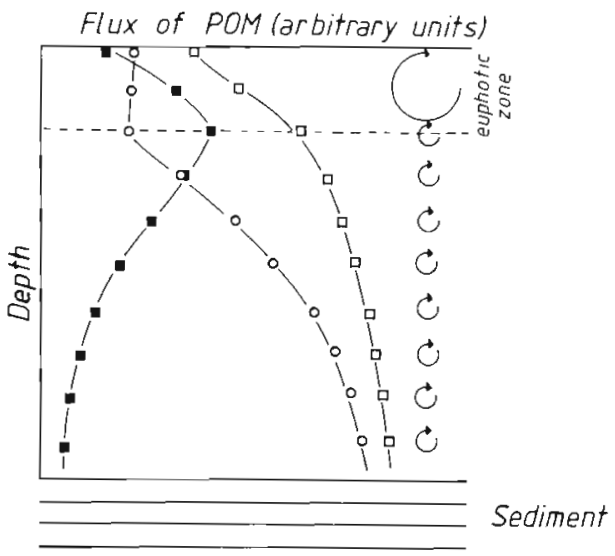

FJORD
口 Gross Sedimentation

- Net Sedimentation

- Secondary Sedimentation

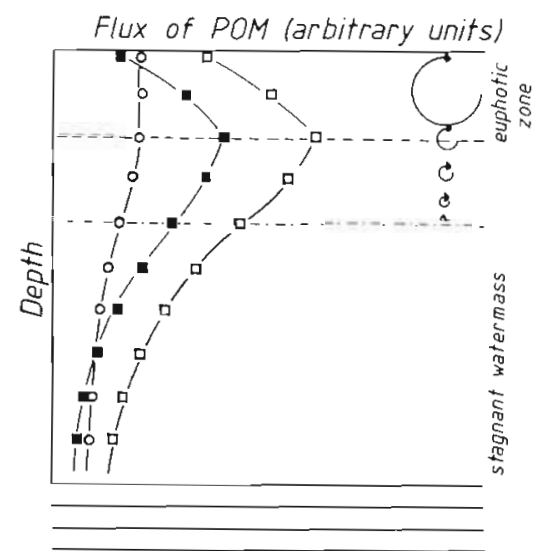

POLL
Fig. 5. General diagram showing the principal differences of particulate organic matter deposition in fjords and polls 
transport (indicated by arrows), which is strongest in the upper part of the water column, leads to resuspension of particulate material from the bottom and the sides in fjords. This resuspended material is mixed with primary settling material. Turbulent water movement can also cause primary settling material to pass the same depth horizon several times in the course of its overall progress downwards. Thus turbulent water movement gives rise to increased quantities of material settled in collecting vessels. The consequence in fjords is an overall increasing sedimentation with depth. This is not the case in polls. Here turbulent water movement and resuspension are restricted to the upper part of the water column. As turbulent water transport decreases downwards, so does the resuspension (Fig. 5). The diagram gives a possible explanation why gross sedimentation increases in fjords and many other coastal environments down to the seafloor. In polls, however, gross sedimentation increases down to the bottom of the euphotic layer, but decreases below this depth. In the stagnant water, mass gross sedimentation and net sedimentation are close to each other if turbidity flows and sediment focusing do not occur.

Since resuspension is very low below $40 \mathrm{~m}$ sedimentation rates at 40,70 , and $85 \mathrm{~m}$ represent the actual downwards flux of particulate material. Gross sedimentation rates at 10 and $20 \mathrm{~m}$ have to be corrected for the amount of secondary sedimentation before the actual downwards flux can be obtained.

If we look at the period April to November in Lindaspollene as a whole a loose connection seems to exist between the upper $20 \mathrm{~m}$ and the water column below $40 \mathrm{~m}$ (Table 2). In April and May, however, these 2 layers are tightly coupled since pulses of POM settled quickly to the seafloor (Fig. 4). During summer and autumn the particle flux in Lindasspollene is characterised by two regimes of sedimentation. The sedimentation in the upper $20 \mathrm{~m}$ seems to be influenced by freshwater run-off, especially at $10 \mathrm{~m}$ depth (Table 3). Little of this material gets deposited at $40 \mathrm{~m}$ and below. The freshwater supplied material and minor phytoplankton blooms triggered by dissolved nutrient supply from freshwater are, therefore, either consumed in the upper layer or exported out of the area. The influence of this particulate material can also be seen in the increase and decrease of respectively $\mathrm{POC} /$ PON-ratio and POC/TPM (\%) at $10 \mathrm{~m}$ depth compared to $20 \mathrm{~m}$ depth (Fig. 3b) since the freshwater supplied particles can be characterised as poor in nitrogen and high PIM-content.

In many coastal areas during some periods imbalances between the primary and secondary production have been reported (Fransz, 1976; Gieskes and Kray, 1977; Smetacek, 1980a; Peinert et al., 1982). This is often caused by low overwintering zooplankton biomass. Diatom populations from the spring phytoplankton bloom sink, therefore, ungrazed to the bottom. With the presence of a richer zooplankton community in summer and autumn much of the organic material gets recycled in the water column. Most fjords are deep enough for the overwintering of larger zooplankton organisms, such as Calanus finmarchicus, which immediately graze the spring phytoplankton bloom. In polls, however, larger zooplankton organisms are excluded from overwintering due to low oxygen concentration in the deeper parts and due to the shallowness of the sills.

The decrease in dissolved nutrients and especially in silicate brings the spring phytoplankton bloom to an end (Lännergren and Skjoldal, 1976). Skjoldal and Lännergren (1978) observed that major parts of the spring phytoplankton bloom in Lindasspollene disappeared from the water column during $8 \mathrm{~d}$ in late April. They suggested that the bloom sank to the bottom, which implies sinking rates of about $10 \mathrm{~m} \mathrm{~d}^{-1}$. The results of this study show that this actually takes place. The coincidence of phytoplankton blooms (chlorophyll a concentrations, Fig. 4) and elevated POC- and PONsedimentation rates in April and May show that the blooms sank to the bottom in about 7 to $14 \mathrm{~d}$ (exposure time of the traps). This implies sinking rates of 6 to $10 \mathrm{~m} \mathrm{~d}^{-1}$

There is considerable disagreement in the literature about in situ sinking rates of phytoplankton ranging from some $\mathrm{cm}$ to several tenths of $\mathrm{m}$ per day (Lännergren, 1979; Bienfang, 1981; Bodungen et al., 1981). 'Marine avalanches' (Bröckel, 1983), sinking about 10 or even $100 \mathrm{~m} \mathrm{~d}^{-1}$ and including parts or the whole phytoplankton bloom, have been described by several authors (Bodungen et al., 1975; Skjoldal and Lännergren, 1978; Smetacek et al., 1978; Bodungen et al., 1981). This phenomenon coincides with lack of dissolved nutrients and is caused by poor physiological state of the phytoplankton (Bienfang, 1981; Bröckel, 1983). Silicate depletion elicited by far the greatest increase in sinking rates of diatoms (Bienfang, 1982). Biochemical aspects of silicate metabolism of diatoms, which seem to be of more importance than densityrelated variations in the amount of silicate per cell (Bienfang, 1982), and low grazing pressure of zooplankton seem to be the main causes for the supply of phytoplankton biomass to the sea bed at the end of vernal blooms

During summer and autumn, small forms like flagellates predominate the phytoplankton in Lindasspollene (Lännergren, 1976). These organisms manage well at low dissolved nutrient concentrations. The recycling of dissolved nutrients by the rich zooplankton community is sufficient for the phytoplankton in summer and autumn since its biomass is low. During those periods 
primary and secondary production in the upper part of the water column is tightly coupled. Good physiological state of phytoplankton organisms lead to balanced growth, which is reflected in POC/PON-ratios (moles) around 7 (Sakshaug et al., 1983). The balance between the phytoplankton growth rate and the remineralization rate during summer and autumn is reflected in the low POC/PON-ratios of the deposited material in the sediment vessels at all depth (Fig. 3a and 4). During blooms, however, lack of dissolved nutrients leads to nitrogen depletion and high POC/PON-ratios (Fig. 4). The results from Lindasspollene seem to indicate that 'new production' (April) and 'recycled production' (summer and autumn) (in the sense of Dugdale and Goehring, 1967) are well reflected in respectively high and low POC/PON-ratios of the deposited material.

The use of nitrogen content of detritus as an indicator of nutritional value has been criticised by Rice (1982) since much nitrogen accumulated under detritus decomposition is non-labile humic nitrogen rather than microbial protein. In Lindåspollene most of the organic material supply is due to photosynthesis (Table 4) and since the POC/PON-ratios can be used as reliable parameter characterising the physiological state of phytoplankton communities when corrected for detritus (Sakshaug et al., 1983) the ratio seems to be useful in explaining changes in the nature of the deposited material in this study.

In contrast to the results of Steele and Baird (1972), Seki et al. (1974), Bishop et al. (1977), Honjo and Roman (1978) and Spencer et al. (1978) fecal pellets seem to be of minor significance for the flux of the POM to the sea bed in Lindasspollene. Even in periods when zooplankton were abundant, fecal pellets were scarce, especially below $20 \mathrm{~m}$. Also in Kiel Bight (Smetacek, 1980a) small amounts of fecal pellets were found in the sediment traps. The small contribution of fecal pellets in the sedimented material can be interpreted as a result of coprophagy (Turner and Ferrante, 1979), neutral buoyancy (Krause, 1981) and microbial attack on fecal pellets (Paffenhöfer and Knowls, 1979; Smetacek, 1980b; Hofman et al., 1981). If the particle diameter of suspended POM decreases severely in the lower part of the upper water column in Lindasspollene, i.e. due to the effect of grazing herbivores, coprophagy, resuspension of fecal material after the dissolution of the pellicula etc., the sedimentation rate would decrease markedly since the sinking rate of a particle decreases exponentially with decreasing diameter (McCave, 1975). Such a delay in sedimentation would lead to higher pelagical mineralization rates in the water column and, therefore, result in a lower amount of sedimenting material and lower numbers of recognizable particles.

Table 5 compares gross-sedimentation rates from different coastal areas with the results of this study The deposition rates in Framvaren (Skei, 1983) and Lindasspollene are low compared to those from other areas. Polls, therefore, seem to be characterised by low sedimentation rates. The organic content of the deposited material, however, is quite high compared to the results of other studies (Table 5), indicating that inorganic material is of relatively minor significance for the total sedimentation in Lindasspollene.

According to Parsons et al. (1977), 30 to $40 \%$ of the planktonic primary production settles to the sea floor every year in coastal areas. Other sources, such as sewage, allochtonous material, macrophytes etc., might also be of importance. Only $19 \%$ of the POCsupply of Lindaspollene is supplied to the sea-bed at the sampling site (Table 1 and Table 4). Low deposition rates of POC are also known from lakes (Kimmel and Goldman, 1977; Wissmar et al, 1977) and from the glacial embayment Bedford Basin (Hargrave and Taguchi, 1978), where $15 \%$ of the total supply reached the bottom. In contrast to Bedford Basin, where the tidal exchange is large and $57 \%$ of the POC-supply is exporter to the sea, the export of POC from Lindasspollene must be of minor importance. The surface water is highly stratified most of the year and only $2 \%$ of the total water volume is exchanged during one tidal cycle; $28 \%$ of the POC-supply is consumed by planktonic organisms in Bedford Basin. In Lindåspollene, however, planktonic consumption represents probably the main sink for POC supplied to the upper $40 \mathrm{~m}$ (Table 4). Planktonic mineralization rates (\% of primary production) have been estimated for coastal waters like Narragansett Bay (Oviatt et al., 1981: 59\%), open ocean areas (Suess, 1980: 60\%), upwelling areas (Lee and Cronin, 1982: $90 \%$ ), tropical areas (Petersen and Curtis, 1980; Taguchi, 1982: $51 \%$ ), and from the oxic part of the water column of the Black Sea (Deuser. 1971: $80 \%$ ). Thus, it is probable that the planktonic mineralization rate in Lindasspollene is rather high since export is thought to be of minor importance. Compared to a west Norwegian fjord, where the netsedimentation rate of POC close to the bottom comprised $38 \%$ of the primary production (Wassmann, 1981), the flux of POC to the sediment in Lindasspollene comprised only $24 \%$ of the primary production (Table 1 and Table 4). The assumption of Matthews and Heimdal (1980) that planktonic poll communities (characterised by nanoflagellates and small copepods) have at least during certain periods low ecological efficiencies compared to fjords (characterised by a predominance of diatoms and larger copepods) cannot be true for Lindåspollene on an annual basis since the remineralization efficiency of the planktonic community seems to be quite large. The specific structure of the planktonic food-chain and the hydrography of any poll 
Table 5. Annual gross-sedimentation rates of total particulate material (TPM), particulate organic carbon (POC), and POC/TPM $(\%)$ in different coastal environments

\begin{tabular}{|c|c|c|c|c|}
\hline \multirow[t]{2}{*}{ Location and reference } & \multirow[t]{2}{*}{ Depth of trap (m) } & \multicolumn{2}{|c|}{ Sedimentation $\left(\mathrm{g} \mathrm{m}^{-2} \mathrm{yr}^{-1}\right)$} & \multirow[t]{2}{*}{ POC/TPM $(\%)$} \\
\hline & & TPM & $\mathrm{POC}$ & \\
\hline \multicolumn{5}{|l|}{ Depature Bay } \\
\hline Stephens et al. (1967) & 30 & 3000 & 200 & 6.7 \\
\hline \multicolumn{5}{|l|}{ Loch Ewe } \\
\hline Steele \& Baird (1972) & 30 & & 58 & \\
\hline \multicolumn{5}{|l|}{ Loch Etive } \\
\hline Ansell (1974) & 40 & & 106 & \\
\hline & 54 & & 247 & \\
\hline \multicolumn{5}{|l|}{ St. Margareth's Bay } \\
\hline Webster et al. (1975) & 60 & 1500 & 118 & 7.9 \\
\hline \multicolumn{5}{|l|}{ Loch Thurnaig } \\
\hline Davies (1975) & 30 & & 28 & \\
\hline \multicolumn{5}{|l|}{ Bedford Basin } \\
\hline \multirow[t]{5}{*}{ Hargrave et al. (1976) } & 20 & 791 & 58 & 7.3 \\
\hline & 30 & 984 & 71 & 7.2 \\
\hline & 40 & 1076 & 78 & 7.2 \\
\hline & 50 & 1019 & 75 & 7.4 \\
\hline & 60 & 1356 & 92 & 6.8 \\
\hline \multicolumn{5}{|l|}{ Monterey Bay } \\
\hline \multirow[t]{4}{*}{ Knauer et al. $(1979)^{a}$} & $50^{\mathrm{b}}$ & & 158 & \\
\hline & $250^{b}$ & & 92 & \\
\hline & $50^{c}$ & & 33 & \\
\hline & $250^{c}$ & & 19 & \\
\hline \multicolumn{5}{|l|}{ Western Kiel Bight } \\
\hline Snetacek $(1980 a)^{d}$ & 15 & $643-1681$ & $39-80$ & $4.6-5.9$ \\
\hline & 18 & $611-1811$ & $36-104$ & $4.8-6.1$ \\
\hline \multicolumn{5}{|l|}{ Dahob Bay } \\
\hline Lorenzen et al. (1981) & 50 & & 70 & \\
\hline \multicolumn{5}{|l|}{ Kanehohe Bay } \\
\hline Taguchi (1982) & 15 & 1990 & 165 & 8.3 \\
\hline \multicolumn{5}{|l|}{ Fanafjorden } \\
\hline \multirow[t]{2}{*}{ Wassmann (1981) } & 60 & 825 & 96 & 11.6 \\
\hline & 90 & 885 & 107 & 12.1 \\
\hline \multicolumn{5}{|l|}{ Framvaren } \\
\hline Skei (1983, in press) & 40 & 90 & & \\
\hline \multirow{5}{*}{ Lindåspollene (this study) } & 10 & 424 & 53 & 12.5 \\
\hline & 20 & 538 & 110 & 20.5 \\
\hline & 40 & 224 & 29 & 12.9 \\
\hline & 70 & 156 & 26 & 16.7 \\
\hline & 85 & 147 & 23 & 15.6 \\
\hline $\begin{array}{l}\text { a Based on daily flux rates from mea } \\
\text { b Under upwelling } \\
\text { c Under downwelling } \\
\text { d } 3 \text { yr study }\end{array}$ & ods between 19 an & & & \\
\hline
\end{tabular}

or fjord have to be carefully considered before general statements on the recycling efficiencies of those areas can be made.

Acknowledgements. Support of U. Lie and the assistance of A. Aadnesen is gratefully acknowledged. I am grateful to K. v. Bröckel, E. Bonsdorff, 2 unknown referees and especially to $S$.
Blomqvist and H.-R. Skjoldal for offering critical comments on the manuscript.

\section{LITERATURE CITED}

Ansell, A. D. (1974). Sedimentation of organic detritus in Loch Etive and Creran, Argyll, Scotland. Mar. Biol. 27: 263-273 
Aure, J. N. (1972). Hydrografien i Lindåspollene. Unpubl. thesis for the cand. real. degree, University of Bergen, Norway

Ålvik, G. (1934). Plankton-Algen norwegischer Austernpollen. I. Systematik und Vorkommen der Arten. Berg. Mus. Aarbok 1934. Naturvitenskapelig rekke Nr. $6: 1-47$

Bienfang, P. K. (1981). Sinking rates of heterogeneous, temperate phytoplankton populations. J. Plankton Res. 3: 235-253

Bienfang, P. K., Harrison, P. I., Quarmby, L. M. (1982). Sinking rate response to depletion of nitrate, phosphate, and silicate in four marine diatoms. Mar. Biol. 67: 295-302

Bishop, J. K., Edmond, J. M., Ketten, D. R., Bacon, M. P., Siker, W. B. (1977). The chemistry, biology and vertical flux of particulate matter from the $400 \mathrm{~m}$ of the equatorial Atlantic Ocean. Deep Sea Res. 24: 511-548

Bloesch, J., Burns, N. M. (1980). A critical review of the sediment trap technique. Schweizer Z. Hydrobiol, 42: $15-55$

Blomqvist, S., Kofoed, C. (1981). Sediment trapping - a subaquatic in situ experiment. Limnol. Oceanogr. 26: 585-590

Blomqvist, S., Håkanson, L. (1981). A review on sediment traps in aquatic environments. Arch. Hydrobiol. 91: 101-132

Bodungen, B. v., Bröckel, K. v., Smetacek, V., Zeitzschel, B. (1975). Ecological studies on the plankton of the Kiel Bight. I. Phytoplankton. Merentutkimuslait. Julk./Havforskninginstiuts Skr. 239: 179-186

Bodungen, B. V., Bröckel, K. v., Smetacek, V., Zeitzschel, B. (1981). Growth and sedimentation of the phytoplankton spring bloom in the Bornholm Sea (Baltic Sea). Kieler Meeresforsch., Sonderheft 5: 42-67

Bröckel, K. v. (1983). Organic material and its sedimentation. In: Suess, E., Thiede, J. (eds.) Coastal upwelling: its sediment record. Proceedings from a ARI (Advanced Research Institutel symposium, in press

Dahl, O., Østvedt, O. J., Lie, U. (1973). An introduction to a study of the ecosystem and the local herring stock in Lindåspollene. FiskDir. Skr (Ser. Havunders.) 16 $148-158$

Dale, T. (1978). Total, chemical and biological oxygen consumption of the sediments in Lindaspollene, western Norway. Mar Biol. 49: 333-341

Davies, J. M. (1975). Energy flow through the benthos in a Scottish sea loch. Mar. Biol. 31: 353-362

Dean, W. E. jr. (1974). Determination of carbonate and organic matter in calcareous sediments and sedimentary rocks by loss on ignition: comparison with other methods. J. sedim. Petrol. 44: 242-248

Deuser, W G. (1971). Organic-carbon budget of the Black Sea. Deep Sea Res. 18: 995-1004

Devol, A. H. (1981). Vertical distribution of zooplankton respiration in relation to the intense oxygen minimum zones in two British Columbia fjords. J. Plankton Res. 3 : $593-602$

Dugdale, R. C., Goehring, J. J. (1967). Uptake of new and regenerated forms of nitrogen in primary productivity. Limnol. Oceanogr. 12: 196-206

Dybern, B. (1967). Topography and hydrography of Kviturvikspollene and Vågsbøpollen on the west coast of Norway. Sarsia 30: 1-28

Fransz, H. G. (1976). The spring development of calanoid copepod populations in the Dutch coastal waters as related to primary production. In: Persoone, G., Jaspers, E. (eds.) Proceeding of the $10^{\text {th }}$ European Marine Biology Symposium, Ostend, Belgium 2: 247-269

Gaarder, T. (1932). Untersuchungen über Produktions- und
Lebensbedingungen in norwegischen Austern-Pollen. Berg. Mus. Aarbok 1932. Naturvitenskapelig rekke Nr. 3 $1-64$

Gaarder, T., Bjerkan, P. (1934). Østers og østerskultur i Norge. A.s John Griegs Boktrykkeri, Bergen

Gardner, W. D. (1980a). Sediment trap dynamics and calibration: a laboratory evaluation. J. mar Res. 38: 17-39

Gardner, W. D. (1980b). Field calibrations of sediment traps. J. mar. Res. 38: 41-52

Garrels, R. M., Mackenzie, F. (1971). Evolution of sedimentary rocks. W. W. Norton, New York

Gieskes, W. W. C., Kray, G. W. (1977). Primary production and consumption of organic matter in the southern North Sea during the spring bloom of 1975. Neth. J. Sea Res. 11: $146-167$

Gulliksen, B. (1982). Sedimentation close to a near vertical rocky wall in Balsfjorden, northern Norway. Sarsia 67: 21-27

Hargrave, B. T., Phillips, G. A., Taguchi, S. (1976). Sedimentation measurements in Bedford Basin, 1973-1974. Fisheries and Marine Service, Tech. Rep. 608: 1-110

Hargrave, B. T., Kamp-Nielsen, L. (1977). Accumulation of sedimentary organic matter at the base of steep bottom gradients. In: Golterman, H. L. (ed.) Interactions between sediment and freshwater. Dr. W. Junk B. V. Publishers, The Hague, p. 168-173

Hargrave, B. T., Taguchi, S. (1978). Origin of deposited material sedimented in a marine bay. J. Fish. Res. Bd Can. 35: $1604-1613$

Hargrave, B. T., Burns, N. M. (1979). Assessment of sediment trap collection efficiency. Limnol. Oceanogr. 24: $1124-1136$

Hofman, E. E., Klink, J. M., Paffenhöfer, G.-A. (1981). Concentrations and vertical fluxes of zooplankton fecal pellets on a continental shelf. Mar. Biol. 61: 327-335

Honjo, S., Roman, M. R. (1978). Marine copepod fecal pellets: production, preservation, and sedimentation. J. mar. Res. 36: 45-57

Iseki, K., Whitney, F., Wong, C. S. (1980). Biochemical changes of sedimented matter in sediment traps in shallow coastal waters. Bull. Plankton Soc. Japan 27: 27-36

Karlström, U. (1978). Environmental factors, detritus and bottom fauna in the Ricklean - a north Swedish forest river. University of Uppsala, Sweden

Kimmel, B. L., Goldman, C. R. (1977). Production, sedimentation and accumulation of particulate carbon and nitrogen in a sheltered subalpine lake. In: Golterman, H. L. (ed.) Interactions between sediments and freshwater. Dr. W. Junk B. V. Publishers, The Hague, p. 148-155

Klavestad, N. (1957). An ecological study of the vegetation in Hunnebunnen, an old oyster poll in south-eastern Norway. Nytt. Mag. Bot. 5: 63-100

Knauer, G. A., Martin, J. H., Bruland, K. W. (1979). Fluxes of particulate carbon, nitrogen and phosphorous in the upper water column of the North East Pacific. Deep Sea Res. 26: 97-108

Krause, M. (1981). Vertical distribution of fecal pellets during FLEX 76. Helgoländer Meeresunters. 34: 313-327

Lännergren, C. (1975). Phosphate, silicate, nitrate and ammonia in Lindåspollene, a Norwegian land-locked fjord. Sarsia 59: 53-66

Lännergren, C. (1976). Primary production in Lindåspollene, a Norwegian land-locked fjord. Botanica mar. 19: 259-272

Lännergren, C. (1978). Phytoplankton production at two stations in Lindåspollene, a Norwegian land-locked fjord, and limiting nutrients studied by two kinds of bio-assay. Int. Revue ges. Hydrobiol. 63: 57-76 
Lännergren, C. (1979). Buoyancy of natural populations of marine phytoplankton. Mar. Biol. 54: 1-10

Lännergren, C., Skjoldal, H.-R. (1976). The spring phytoplankton bloom in Lindåspollene, a land-locked Norwegian fjord. Autotrophic and heterotrophic activities in relation to nutrients. In: Persoone, G., Jaspers, E. (ed.) Proceedings of the $10^{\text {th }}$ European Marine Biology Symposium, Ostend, Belgium. Vol. 2. Universa Press, Wetteren, p. 363-391

Lee, C., Cronin, C. (1982). The flux of particulate nitrogen in the sea: decomposition of amino acids in the Peru upwelling area and equatorial Atlantic. J. mar. Res. 40: 227-251

Lorenzen, C. J., Shuman, F. R., Bennett, J. T. (1981). In situ calibration of a sediment trap. Limnol. Oceanogr. 26: 580-585

Matthews, J. B. L., Heimdal, B. R. (1980). Pelagic productivity and food chains in fjord systems. In: Freeland, H. J., Farmer, D. M., Levings, C. D. (ed.) Fjord oceanography, NATO conference series, IV, Marine science. Plenum Press, New York, p. 377-398

McCave, J. N. (1975). Vertical flux of particles in the ocean. Deep Sea Res. 22: 491-502

Newbern, L. A. (1981). Organic matter transport in an Appalachian montain river in Virginia, USA. Hydrobiologia 83: 73-83

Oviatt, C. A., Buckley, B., Nixon, S. W. (1981). Annual phytoplankton metabolism in Narragansett Bay calculated from survey field measurements and microcosm observation. Estuaries 4: 167-175

Paffenhöfer, G.-A., Knowls, S. C. (1979). Ecological implications of fecal pellet size, production and consumption by copepods. J. mar. Res. 37: 35-49

Pamatmat, M. M., Skjoldal, H. R. (1974). Dehydrogenase activity and adenosine triphosphate concentration of marine sediments in Lindåspollene, Norway. Sarsia 56: $1-12$

Parsons, T. R., Takahaschi, M., Hargrave, B. T. (1977). Biological oceanographic process, 2nd ed. Pergamon Press, Oxford

Peinert, R., Saure, A., Stegman, P., Stien, C., Haardt, H., Smetacek, V. (1982). Dynamic of primary production and sedimentation in a coastal ecosystem. Neth. J. Sea Res. 16: 276-289

Petersen, G. H., Curtis, M. A. (1980). Differences in energy flow through major components of subarctic, temperate, and tropical marine shelf ecosystems. Dana 1: 53-64

Platt, H. M. (1979). Sedimentation and distribution of organic matter in a sub-arctic bay. Estuar. coast. mar. Sci. 9: 51-63

Rice, D. L. (1982). The detritus nitrogen problem: new observations and perspectives from organic geochemistry. Mar. Ecol. Prog. Ser. 9: 153-162

Sakshaug, E., Andresen, K., Myklestad, S., Olsen, Y (1983). Nutrient status of phytoplankton communities in Norwegian waters (marine, brackish and fresh) as revealed by their chemical composition. J. Plankton Res. 5: 175-196

Seki, H., Tsuji, T., Hattori, A. (1974). Effect of zooplankton grazing on the formation of the anoxic layer in Tokyo Bay. Estuar. coast. mar. Sci. 2: 145-151

Sholkowitz, E. R. (1976). Flocculation of dissolved organic and inorganic matter during the mixing of river water and sea water. Geochim. cosmochim. Acta 40: 831-845

Skei, J. (1983). Geochemical and sedimentological considerations of a permanent anoxic fjord - Framvaren, south Norway. J. sedim. Geol., in press

Skjoldal, H.-R., Lännergren, C. (1978). The spring phytoplankton bloom in Lindåspollene, a land-locked Norwegian fjord. II. Biomass and activity of net-and nanoplankton. Mar. Biol. 47: 313-323

Smetacek, V. (1980a). Annual cycle of sedimentation in relation to plankton ecology in Western Kiel Bight. Ophelia 1 (Suppl.): 65-76

Smetacek, V. (1980b). Zooplankton standing stock, copepods fecal pellets, and particulate detritus in Kiel Bight. Estuar. coast. mar. Sci. 11: 477-490

Srnetacek, V., Bröckel, K. v., Zeitzschel, B., Zenk, W. (1978). Sedimentation of particulate matter during a phytoplankton spring bloom in relation to the hydrographical regime. Mar. Biol. 47: 211-226

Sokal, R. R., Rohlf, J. F. (1981). Biometry, 2nd ed. W. H. Freeman and Co., San Francisco

Spencer, D. W., Brewer, P. G., Fleers, A., Honjo, S., Krishnawami, S., Nozaki, Y. (1978). Chemical fluxes from a sediment trap experiment in the deep Sargasso Sea. J. mar. Res. 36: 493-523

Steele, J. H., Baird, I. E. (1972). Sedimentation of organic matter in a Scottish sea loch. Memorie Ist. ital. Idrobiol. 29 (Suppl.): 73-88

Stephens, K., Sheldon, R. W., Parsons, T. R. (1967). Seasonal variations in the availability of food for the benthos in a coastal environment. Ecology 48: 852-855

Strøm, K. M. (1936). Land-locked waters. Hydrography and bottom deposits in badly ventilated Norwegian fjords, with remarks upon sedimentation under anaerobic conditions. Skr. norske Vidensk-Akad. Oslo 1 (7): 1-85

Suess, E. (1980). Particulate organic carbon flux in the oceans - surface productivity and oxygen utilization. Nature, Lond. 288: 260-262

Taguchi, S. (1982). Sedimentation of newly produced particulate organic matter in a subtropical inlet, Kaneohe Bay, Hawaii. Estuar. coast. Shelf Sci. 4: 533-544

Turner, I. T., Ferrante, I. G. (1979). Zooplankton fecal pellets in aquatic ecosystems. BioScience 29: 670-677

Wassmann, P. (1981). Sedimentering og benthosmetabolisme i den indre delen av Fanafjorden. Unpubl. thesis for the cand. real. degree, University of Bergen, Norway

Webster, T. J. M., Paranjape, M. A., Mann, K. H. (1975). Sedimentation of organic matter in St. Margareths Bay, Nova Scotia. J. Fish. Res. Bd Can. 32: 1399-1407

Wissmar, R. C., Richey, J. E., Spyridakis, D. E. (1977). The importance of allochtonous particulate carbon pathways in a subalpine lake. J. Fish. Res. Bd Can. 34: 1410-1418 